\title{
Extractive industry a burden or an opportunity for sustainable development?
}

\author{
Dr. Aurela SHTIZA ${ }^{1}$
}

\begin{abstract}
:
The shortage of raw materials in global markets and the sky rocketing of commodity prices, have induced European authorities to take initiatives to improve innovation in Europe by creating the European Innovation Partnership on Raw Materials (2012) and make inventory of the existing European raw materials. Albania is a rich country in natural raw materials, such as chromium, copper, ferronickel, coal, bitumen as well as crude oil which might supply primary and secondary raw materials for some of the European needs. This literature review discusses the role of the Albanian institutions, the natural resources industry, potential investors and stakeholders in order to provide a set of indicators and platforms that can help to develop the extractive industry in Albania and monitor amelioration within sustainable development principles. A map with the potential prospects of the natural resources will be a first step in identifying the further potential for exploitation. Mineral resource policies and governance, sustainable processing and supply chain as well as environmental management information system (EMIS) are some of the crucial tools identified, which will help to set up the indicators and quantify the achievements in environmental management in Albania. Moreover, the integration of practices that will support institutional capacity building; follow-up practices; the mainstreaming of global environment into planning; and the compliance monitoring process will additionally improve the environmental situation in Albania. Aligning business strategy with environmental policy, socio-economic analysis, environmental auditing are decisive tools in order to provide the Albanian authorities with a clear overview of the economic costs and the social benefits for sustainable development of the extractive sector in Albania.
\end{abstract}

Key words: Environmental Management Information System (EMIS); sustainable development; natural resources; economy; industry; waste; environment;

\section{Introduction}

The fundamental principle of sustainable development is to serve the essential needs of the mankind at present while at the same time protecting and ensuring the needs of the future generations. Economic, environmental and

${ }^{1}$ Previous address: Katholieke Universiteit Leuven, Geo-Institute, Celestijnenlaan 200E, B-3001 Heverlee, Belgium,

Current address: IMA-Europe, Rue de deux Eglises 26/2, 1000 Brussels, Belgium 
social concerns constitute the three basic pillars of the sustainable development principles [WCED, 1987]. Raw materials are essential for the sustainable functioning of modern societies. Access to and affordability of mineral raw materials is crucial for the sound functioning of the world and European economy in particular. Sectors such as construction, chemicals, automotive, aerospace, machinery and equipment sectors which provide a total value added of $€ 1324$ billion and employment for some 30 million people in Europe alone all depend on access and quality of raw materials. Securing reliable and undistorted access to raw materials is increasingly becoming an important factor for the EU's competitiveness and, hence, crucial to the success of the Lisbon Partnership for growth and jobs [EC, 2008a]. Although Europe has a high potential in reserves and exploration, the European mining has decreased over the last years due to the issues related to access to land, price of energy, employment costs and so on. In order to facilitate the sustainable supply of raw materials from European deposits, it is important to have the right legal and regulatory framework conditions in place [COM (2011) 25)]. Over 50\% of major mineral reserves are located in countries with a per capita gross national income of $\$ 10$ per day or less. This creates new opportunities for these resource-rich developing countries, particularly in Africa [EC, 2008b], to significantly increase their national income since many of them are still facing poverty or slow growth. However some of these countries are facing violent conflicts, sometimes fuelled by competition for control of natural resources and some lack governance, notably as regards the allocation of resource revenues. Furthermore, these countries have often difficulties negotiating with foreign mining companies due to asymmetric information about the value of deposits and insufficient administrative resources. Emerging countries are also pursuing strategies towards resource-rich countries with the apparent aim of securing privileged access to raw materials. For example, China and India have substantially increased their economic engagement with Africa in recent years; in the case of China this includes major infrastructure projects and active involvement in exploration and extraction activities in countries such as Zambia (copper), Democratic Republic of Congo (copper, cobalt), South Africa (iron ore), Zimbabwe (platinum) and Gabon, Equatorial Guinea and Cameroon (timber) [EC, 2008a].

Commodity markets have displayed increased volatility and unprecedented movements of prices in recent years. Prices in all major commodity markets, including energy, metals and minerals, agriculture and food, increased sharply in 2007 to reach a peak in 2008, declined strongly from the second half of 2008 due to the economical downturn and have been on an increasing trend again since the summer of 2009. To varying degrees, these price swings have been reflected in consumer prices, at times leading to social unrest and deprivation [COM (2011) 25)]. The commodity price fluctuations, in the period 2002 to 2008 were 
marked by a major demand for raw materials, driven by strong global economic growth, in particular in emerging countries such as China. This increase in demand will be reinforced by the further rapid industrialisation and urbanisation in countries such as China, India and Brazil. The high demand for raw materials and low extraction taking place in the developed countries, have increased the pressure on developing countries into increasing the exploration and exploitation potential in order to supply raw materials for the immediate needs for the developed countries. Asia (China, India, Iran,) Africa (Democratic Republic of Congo, South Africa), and Latin America (Chile, Venezuela, Colombia) are some of the main suppliers for the raw materials contributing to the immediate needs of developed countries. However, due to the high demand and to a certain extent to the monopoly these emerging economies and developing countries have in raw material deposits, there might also be problems in delivery of these raw materials, as well as price distortion in global markets. The case of China, which blocked the delivery of rare material to Japan for an undermined period in September 2010, due to a so-called 'boat incident' where a Chinese and a Japanese boat were involved, is one example of such dependency. Another factor to be kept in mind is also the society trends, which developing the IT technologies, such as phone, laptops determine the need for specific raw materials such as rare earth in the mobile revolution in early 2000 [EC, 2008a,b]. In view of the shortage of raw materials in global markets and the increase in commodity prices the industrialised countries have taken action to define raw material strategic plans on long term and ensure the continuous supply based on their needs. Japan and the US have recognised their critical dependence on particular raw materials and are pursuing specific policies for safeguarding their raw material supply. The US, for example, has defined raw materials that are strategically relevant and also maintains a stockpile of raw materials that are crucial for the defence industry. Japan has also engaged in ensuring the critical access to raw materials (Annex 7, [EC, 2008b]). Raw Materials Initiative strategic document [COM (2011) 25)] and the European Innovation Partnership on Raw Materials (EIP launched in January 2013) are the European strategic initiatives which aim to increase the availability of raw materials for Europe and address the challenges for future raw material supply and contribute to the 2020 targets of the EU Industrial Policy. In addition various EU funded projects (such as ProMine), or other European technology platforms on sustainable mineral resources (ETP-SMR) were launched over the last years in order to address the challenges of raw material shortage. These initiatives aimed at developing innovative exploration and extraction technologies that will maximize economic and environmental benefits for European industry.

Albania is a rich country in natural raw materials, such as chromium, copper, ferro-nickel, coal, bitumen as well as crude oil due to the presence of favorable 
geological formations, such as the ophiolites for the ores and the carbonate rocks for the oil and gas deposits [Meço et al, 2000]. The history of assessing mining potential and exploration in Albania can be subdivided into three major stages:

1. Post World War First. The period 1919 -1939 was marked by the finalization of the first geological map of Albania (1922) and assessment of the potential for raw material exploration;

2. Post World War Second. The period 1944-1990, was characterized by a dictatorship regime and centralized economy which was characterized by a massive exploration of primary raw materials (chromium, iron, nickel, copper, oil, coal and various industrial minerals) in state controlled enterprises;

3. The post communist period. The period from 1990 onwards, was characterized by a long transition period (changes in the political system into a democracy the decentralization of the economy), and variable raw material extraction trends.

Its communist legacy, which dictated the development of various industrial sectors, followed by a political transitional period characterized by apathetic institutions, aggravated land contamination and additional negative environmental impacts for Albania during the period 1950-2009. These raw materials have been extensively exploited in unsustainable manner in the last 5 decades. The aim of the Albanian authorities is to continue the further exploitation, but some major problems such as the legal framework for the concessions, environmental control, issues related to past contamination are factors which hamper the further development of the mining sector in Albania. Considerable assistance from the UN [UN Albania], and EU [EEA, 2010] in various initiatives have helped to prepare the relevant legal framework, but still there is a lot to be done in the implementation and follow-up by the national authorities. Mineral resource policies and governance, sustainable processing and supply chain as well as environmental management information system are some of the key tools that will help to set up the indicators and quantify the achievements in environmental management in Albania.

This review will aim to illustrate the case of Albania, as country that can satisfy some of the demands of the EU market for some key raw materials. To achieve a sustainable resource use, the strong collaboration between potential investors, local and Albanian authorities in respect to sustainable development and environmental protection shall be critical to accommodate long term investments by potential investors. 


\section{Problem statement}

The map of the main natural resources and their exploitation and treatment sites for Albania are shown in Fig. 1. A large number of small and some large sized ore deposits have been mined and partly treated in intensively in the 1944-1990 and much less intensively in the period after 1990, due to the transition period and the general overall economical and political instability [MPTI, 2000]. Its communist legacy (1944-1990), which dictated the development of various industrial sectors, followed by a political transitional period (1991-2005) was characterized by apathetic institutions, aggravated land contamination and additional negative environmental impacts. Although there are no records for the entire exploitation period, only in the period 1986-1996 were exploited: 25 million tones of limestone; 7.1 million tones of chrome ore (i.e. 1989 third place in world scale for the extracted volumes); 6.8 million tons of copper ore; 5 million tons iron-nickel ore; 12.5 million tons of coal; 100000 tones of natural bitumen; 500000 tons of bituminous sands [MPTI, 2000].
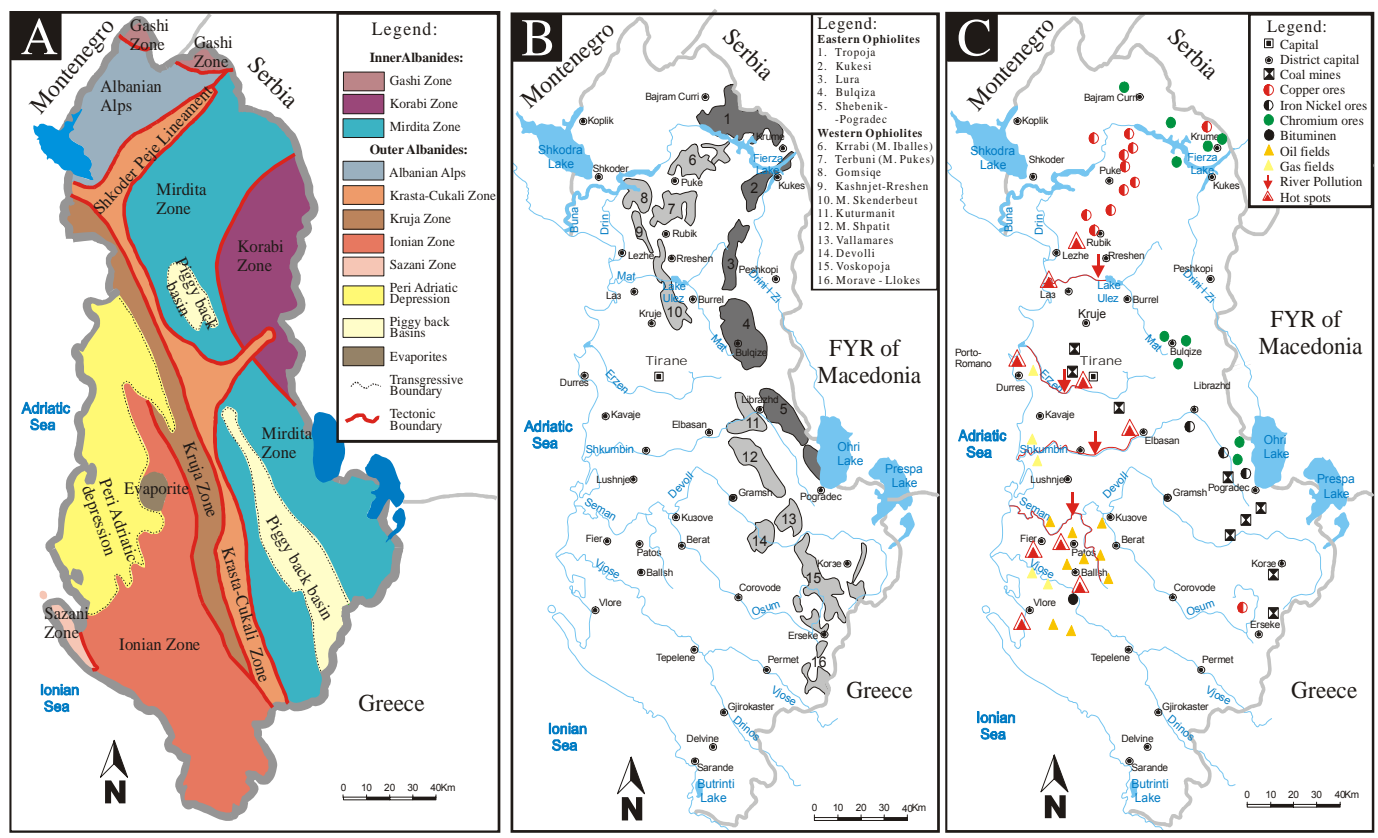

Figure 1 A The main geological units of Albanides [Meço et al., 2000; V ranai at al., 1997]; B. Eastern and Western Ophiolite Belt (respectively EOB and WOB) with indication of the main chromite ore massifs occurring within the Mirdita Zone V ranai at al., 19977; C. Map of the main mineralogical resources in Albania with identified hotspots due to industrial activities [Meço et al, 2000; UNDP, 2010]

The operational conditions in these industrial sites had no risk management measures integrated, meaning the wastes were generally dumped outside the 
production and/or treatment sites without any additional pre-treatment. As a consequence of the negative effects of mining and mineral processing on the environment, soils and sediments in the neighbourhood of the mines and industrial sites, but also along the traffic roads and nearby rivers were often extremely polluted [UNDP, 2010]. Majority of the former intensively used (or exploited) sites are not operational anymore, however the environmental threat still exists due to negligence, unawareness and financial constraints. These sites are now characterized by lack of vegetation, the absence of "real" infrastructure and solid wastes (i.e. construction debris) or other waste materials are dumped in these abandoned spots due to the absence of landfill or recycling installations [Cara, 2003; Shtiza at al., 2005; 2008; 2009a, b]. The major problem is that the contamination is spreading out. Metal-bearing particles from contaminated areas can be transported by water, into the river systems causing downstream spreading of the contaminants in riverbed and alluvial plain sediments as shown by [Rivaro et al, 2004; Shtiza et al, 2005; Shtiza 2009b; UNDP, 2010]. An additional transportation pathway are the dust particles, which are being spread due to windblown particles in distances up to several kilometers from the point industrial source as shown by [Shtiza at al., 2005; Tashko, 2006; Shtiza et al., 2009b; Shtiza and Tashko, 2012]. Moreover the easy access of people living in the vicinity of these sites makes them hazardous spots with respect to the long term exposure for population. Awareness about these problems is increasing, but concrete actions are scarce mainly due to economical constraints.

The EU authorities and institutions assisted in preparing qualitative legislations, such as Law on Environmental Protection (2002), Law on Environmental Impact Assessment (2003). However, the strength of the government and other institutions is questionable when it comes to enforcement and follow-up of the environmental conditions and mitigated actions. Additionally the social pressure is highly dependable on the economic situation of the nearby community. It is of common knowledge that the situation in the surrounding of the Elbasani metallurgical complex is very severe as shown by various studies in the area [Qiriazi and Sala, 2000; Sallaku and Shallari, 2003; Tashko, 2006; Sallaku at al., 2009; Shtiza at al., 2009; Mazreku et al, 2010; Shtiza and Tashko, 2012], however for the inhabitants living in the surrounding, on the short term the Elbasani metallurgical complex is a source of work and economic income. Based on a cost estimate from the UNDP program in Albania [UNDP, 2010], the cost to remediate only the ferrochromium smelter in Elbasani is estimated to be around 40 Million Euros, together with 25.000 Euros yearly operational costs related to environmental monitoring and follow-up actions. 


\section{Discussion}

As it is shown in the resource map of Albania (Fig. 1C), there is a enormous potential to develop further the raw material extraction. The mining industry can play a central role in community development by acting as a catalyst for positive change in areas that may be otherwise have little if any opportunities for economic and social development. Mining and exploration activities, can act as a catalyst to help to build up other non-mining sustainable income sources and thus are able to survive the exhaustion of the ore reserves or the departure of the mining operation. Extractive industry can contributes to sustainable development by integrating economic growth with environmental protection, social development and effective governance of local communities.

As is clear from the data shown, that past intense exploitation has eroded and/or damaged the natural capital of Albania and on the long term development will not be successful, due to the large costs involved in the remediation and rehabilitation of specific sites. The European principle [EU 2004/35/CE, 2004] "the polluter pays" can't be applied in the specific case of Albania, since the state has not the economic potential to afford the costs of past policies. More important, polluter pay for externalities is that property rights over the environment are defined and enforced. Environment does not belong to one generation, thus sensibilization and action must be undertaken as soon as possible in order to minimize the past environmental damage for the future sustainable development. The case for environmentally and socially sustainable business grows ever stronger. Businesses must be adaptable, resilient and responsive. The challenge now is how to balance effective business management with responsible extraction practices.

This can be achieved in one hand with the intervention of the concerned institutions (Ministry of Economy, Ministry of Environment, geological survey, monitoring institutes) by identifying key economical potential for exploration, by preparing a system that contains all the data available on past exploration and predictions for future potential (prospectivity) map of Albania (Figure 2). On the other hand the Albanian institutions shall prepare a sustainable development action plan on country scale where the mining and future prospects shall be incorporated as possible crucial sectors for potential development. These two key documents altogether with transparent legal policies shall be the businesscard of the Albanian authorities which shall be used to attract potential investors. The preparation of these documents will need a lot of time, experience and will be costly, however, this will provide the platform to establish the exploration potential as well as link with prospective small, medium and/or large investors that are aimed at. Kosovo, has prepared a similar document, which has been very 
useful to potential investors for screening in timely manner the raw material potential of Kosovo [Knobloch et al., 2010].

Actions toward sustainable development require a mix of scientific, economic, social and political knowledge and visionary judgment of the concerned stakeholders.

Therefore participation, integration, learning, and negotiation are the key steps which can be better understood within the context of shared responsibility,

\begin{tabular}{|c|}
\hline Institutional strengthening \\
$\downarrow$ \\
\hline Prepare a prospectivity map of Albanian resources \\
\hline \\
\hline Adapt environmental managment and enforce it \\
$\downarrow$ \\
\hline Apply cost beneffit analysis in the early phase of project(s) \\
\hline \\
\hline Plan and check the environmental compliance \\
with monitoring process \\
$\downarrow$ \\
\hline Environmental management information system \\
$\downarrow$ \\
Include the environmental indicators \\
into the decision making process
\end{tabular}

Figure 2: Flowchart showing the main actions to implement the sustainable development of extractive sector in Albania.

embedded within larger systems of power and knowledge that evolve and change over time [Kerkhoff and Lebel, 2006]. This can be achieved by the clear vision of the ministries in charge of setting the strategic vision and ensuring the involvement of local authorities in order to involve all the concerned stakeholders and ensure substantial investments and overall sustainable development takes place. Figure 3 illustrates the interaction of various players in decision making process. 


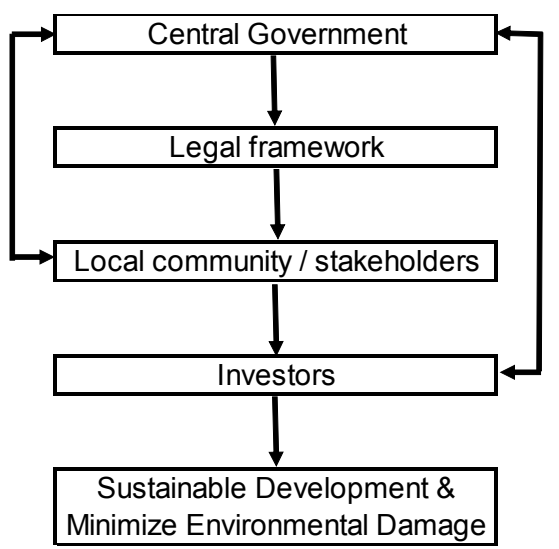

Figure 3: The interaction of various players in the decision making for key investments in extraction sectors

Under the One UN Programme, sustainable development will be incorporated in the policies and strategies of sectors such as energy, agriculture, tourism, forestry and industry, observing the commitments of the Albanian Government within the EU accession process [UN Albania, 2013]. The role of central government in changing the fiscal policy could provide market-based incentives for individuals and companies to minimise the past environmental damage. By inducing innovation, the costs to comply with new environmental standards and policies are dramatically reduced for companies, therefore the better the performance, the more profitable the fiscal policy for these eco-friendly companies [Roodman, 1998]. This potential in Albania is restricted, due to the large costs involved in starting-up the investments due to the legacy of contaminants, the stability in political and economical reforms and the assurances needed by potential foreign investors for macro stability in general in order to ensure that long term investments will pay back.

In developed countries environmental regulations make companies more innovative and fit for the future, as environmental protection is also a positive investment for the economy [BMU \& UBA, 2009; German Ministry of Environment, 2009]. It reduces follow-up costs resulting from environmental damage that society would otherwise have to bear. Some key tools for greening the industry are the following: voluntary initiatives and prevention principle; taxation benefits; environmental management systems indicators as well as integrated prevention pollution control (IPPC) through best available techniques (BAT) and principles. The technological limitations in Albania at the time of industrialization (i.e. release of unfiltered emissions, dumping of waste) resulted in spreading of the contaminants on relatively large scale and the exposure of humans and biota especially near the former industrial sites. The chromium slags can be considered also as a potential economic resource, since they contain up to $50 \%$ chromium ore which can be reprocessed [MPTI, 1997; Shtiza et al, 2005]. 
Using efficient, innovative and cost-effect BAT techniques that could maximize the quantities of commercial raw material from ores, availability of available markets for waste streams or re-processing waste can be considered in line with resource efficiency and sustainable development principles. A study conducted from the Mining and Processing Technology Institute of Albania, indicated that by treating up to 120000 tons of Chromium slag could recover up to $3300 \mathrm{t}$ (or up to $37 \%$ ) of ferrochromium powder [MPTI, 1997]. This study was not applied due to the political changes and the economical implications, but in the future can be considered as a sustainable project in order to minimize the amount of slags accumulated over the years and reduce the release of heavy metals into the surrounding environment. Thus, more flexible approaches would give new market incentives to clean up these old abandoned sites more efficiently and become beneficial to the small communities and the environment. Thus, new investments shall be agreed upon the implementation of environmental friendly technology and the control of the waste deposition sites. [Pezzey, 1992] indicated that resource-using investments are more common than the resource saving investments. This is due to the fact that by using environmental policy, the resource prices will go up, the investments will be shifted towards resource saving and thus reducing the total investment demand. Therefore, the goal of the policy developers shall be to support and prioritize sustainable projects, using cost-benefit analysis in the early stages of the projects.

One obstacle in the application of environmental policy is the problem of the property rights. During the communist period, everything was state owned, while property is one of the main pillars which steers the free market economy and boosts the overall development. When the contamination occurred, the soil/land or the object 'belonged' to the state, but now this might be property of someone. Since the state can't afford to pay for the site remediation, this becomes an obligation for the private investor. So the development of a new economical/industrial activity shall consider major costs for a clean-up plan. Since the starting costs become considerable, private initiative is limited from an early stage of the investment phase. The experience from developed countries has shown that environmental improvement is generally compatible with economic growth in the mature stages of the development. But, as is the case of Albania the environmental policy is presently weak, being in the early stage of the industrialization and economic development. Therefore alternatives, such as tax benefits in regenerating brownfields and/or polluted areas might be considered as possible incentives to regenerate and develop specific industrial sites.

The policy makers emphasize the investments targeting economic development, while for the regeneration of the environment and protection there is no strategy due economic restrictions. The effects of the delay in investing for the protection 
of the environment are difficult to predict, however one thing is clear; a big investment today may have a large impact in the future. By investing 0.6 billion $€$ in the period 1990-1992, the Federal German government not only improved the environmental conditions by minimizing the waste release, but also created employment possibilities for more than 120000 people [Hallstrom, 1999]. A similar approach can also be applied in Albania, however important to know is that the primary investments are considerable and not readily available.

Costs of reversing environmental damages in Albania, and the implementation of sustainable development policies and technologies, are so enormous that Albania alone will be unable to meet them. Thus the help of the EU, and other developed countries and/or international organizations such as International Monetary Fund, World Bank , ... in the form of significant and long term economic and technological aid will be mostly to initiate awareness at institutional level and action trend on a regional/community level. The lack of this aid may lead to further decline in the environmental quality in the present Central European Countries and the EU. This ability to impact the EU's environment could be the major factor in a decision by the EU to implement environmental taxes against these states, as pointed out by Hallstrom [1999]. The sustainability in the context of non-renewable and renewable resources can be considered in combination with the cost benefit analysis (CBA) in order to minimize the future damage of the environment [Shtiza and Swennen, 2005]. While in EU and USA, the amount of CBA that take into account the environmental impacts being undertaken has increased, its influence on policy making is still open to question. Nonetheless, CBA has begun to have influence in the setting of environmental taxes and alternative decision rules appear to suffer as many, if not more, shortcomings as those faced by CBA [Hanley, 1992; Pearce, 1998]. It is often forgotten that mining is a temporary use of land, whose immediate impact can be masked and minimized by the use of the appropriate technology, and which can create great wealth for the community of the direct concerned stakeholders and communities. The mining industry needs to maintain high standards, both for the health and safety of its workforce, the wider community and for the local environment. The environment in various developing countries is suffering today, partly because it has not met proper standards in the past [Crowson, 1996]. By using CBA in the early investment phase, and considering exploration, waste reduction as well as environmental protection throughout the life of a mine from its exploration until its closure, are some key steps which will help to minimise the environmental damage and human exposure. Improving the management strategies implies to have a long term vision for the future while making decisions now.

Monitoring is the only way to observe the improvement or the deterioration of the environmental conditions by a specific industrial activity. Converting the data 
from individual reports and studies into a common database into an Environmental Management Information System (EMIS) on the short term will give a general idea on environmental conditions and their compartment interaction, while on the long term will assist to observe trends and define needs for further action. Only by compiling data by independent monitoring bodies, the generation of information and knowledge can be directly used by policy makers to incorporate in large development strategies. Generation of reliable data from standardized international techniques that cover extensively the surface of Albania and monitor in regular periods of time shall be an objective of the ministry or ministries under which the monitoring bodies are depending. Goals, indicators, targets, trends, driving forces, and policy responses are crucial to measure and quantify sustainable development as shown by Parris and Kates, [2003].

The non-exploitation strategy will not solve the past environmental contamination, but it is important to recognise that environmental contamination will not vanish if we do nothing. So there is a need for action, and sustainable exploitation can be a first step to control the impact and minimize the past wrong doings. The mining exploration practices of today might be acceptable to the existing knowledge and best practice, but in 10, 20 years time this might be considered as non feasible, or not sustainable. So exchange between industry and policy makers is crucial in order to share the best available practices and advance in knowledge.

The political changes in Albania were associated with an economic shift from a heavy industry into tourism and light industry orientation. Building up adequate strategies for business development, economic prosperity and being aware of the impact on the environment are the challenges that lie in front of the Albanian authorities in order to comply with sustainable development. The use and exploration of raw materials cannot be seen as a standalone concern, but rather as an integral part of environmental issues which await the action of the Albanian authorities, together with pressure arising from new consumption patterns, the impact of global climate change, and biodiversity loss [EEA, 2010]. Albania has begun to implement a new Integrated Planning System (IPS) in an ambitious effort to streamline its policy development processes and integrate numerous planning frameworks such as the National Strategy for Development and Integration (NSDI), the Millennium Development Goals (MDGs), and the NATO Partnership for Peace. The IPS will align government decision-making behind a coherent and coordinated long-term vision, ensuring investment decisions are made within the framework of the Medium-Term Budgeting Process. The IPS also provides a framework for government consolidation and monitoring of international assistance [UNEP Albania, 2013]. Sustainable development should be incorporated in the policies and strategies of various 
sectors such as energy, agriculture, tourism, forestry and industry, observing the commitments of the Albanian Government within the EU accession process. Therefore effective governance, promotion of safe use, recycling, disposal of waste in accordance with existing legislations, as well as understanding changes through time are some of the key issues standing in front of authorities and potential investors [Shtiza, 2010]. Environmental and social responsibilities are at the heart of management practices and will result successful in securing the longterm future of the companies operating in raw material extraction and marketing fields.

\section{Conclusions}

This review shows the close link between economic development and the role of environmental policies. Environmental protection generally pays-off on the long term, as confirmed by the experience of the industrialized countries. Thus the use of the previous experiences can be of great benefit in the efficient use of renewable and non-renewable resources for the development of a sustainable strategy for the extraction industry by mitigating negative past impacts on the Albanian environment. The strengthening of the institutions combined with the establishment of an environmental management information system will improve environmental conditions, but time is required to implement indicators and observe the results arising from mitigation measures. Some of the key indicators that will improve sustainable development in Albania are the strengthening of the institutions; solid legislative background, awareness of international best practices on environmental indicators; conducting costbenefit analysis in the early phase of a development project and the inclusion of environmental indicators in the decision making process for selecting the potential investors in the field of extraction. The growth in the industrial extraction sectors cannot be achieved as a standalone objective. To attain a sustainable development of Albania an integrated approach in various sectors such as land use, energy efficiency, industry development, biodiversity, shall be visionary to ensure meeting the sustainable development goals and ensure social and economic development of overall Albanian society.

\section{Acknowledgements}

This work was initiated in the frame of the $\mathrm{PhD}$. The partial funding from the Katholieke Universiteit of Leuven (East European Initiatives Project 3E000659) is kindly acknowledged. The views presented here are the ones of the author. 


\section{References}

BMU \& UBA, 2009. Executive summary report on the environmental economy 2009. Federal Ministry for the Environment Nature Conservation and Nuclear Safety (BMU) \& Federal Environmental Agency (UBA). Eds. Franz P., Mayer F., Burger A., Schwermer S., Pp. 1-8.

Cara F. Heavy metal as indicators of pollution in the ecosystem of the industrial Laçi zone. Doctoral thesis, 2003.

COM (2011) 25. 2011. Raw Materials Initiative strategic document: Tackling the challenges in commodity markets and on raw materials. Pp. 1-23.

Crowson P. 1996. The European mining industry: What future? Resources Policy 22: 99-105.

EC. 2008a. Commission of the European Communities: The raw material initiative Meeting our critical needs for growth and jobs in Europe. SEC 2741, 1-17.

EC 2008b. Commission of the European Communities: The raw material initiative Meeting our critical needs for growth and jobs in Europe. SEC 699, 1-17.

EEA, 2010. Environmental trends and perspectives in the Western Balkans: future production and consumption patterns. European Environment Agency. Copenhagen, Denmark. Pp. 1-171.

EIP RM. 2013. http://ec.europa.eu/enterprise/policies/raw-materials/innovationpartnership. European Innovation Partnership in Raw materials. Website visted on January 2013.

ETP-SMR. European Technology Platforms on Sustainable Mineral Resources. http://www.etpsmr.org/ Website visted on February 2013.

EU Directive, 2004. Environmental liability with regard to the prevention and remedying of environmental damage. Directive 2004/35/CE of the European Parliament and of the Council. Official Journal of the European Union. Pp. 5675.

German Ministry of Environment, 2009. Report on the Environmental Economy. http://www.bmu.de/english/publication/publ/43696.php Website visted on January 2013.

Hallstrom LK. 1999. Industry versus ecology: environment in the new Europe. Futures 31: 25-38.

Hanley. 1992. Are there environmental limits to cost-benefit analysis? Environmental and Resource Economics. 2/1: 33-59.

ISPGJ and IGJN. Geological Map of Albania. 1983. Instituti i Studimeve dhe Projektimeve të Gjeologjisë and Instituti i Gjeologjisë dhe Naftës. Sc. 1: 200000. (in Albanian).

Knobloch A, Legler C, Barth A, Rexhaj A. 2010. Geology and Minerals of Kosovo Perspectives for National Development. XIX Congress of the Carpathian_Balkan Geological Association. 23-26 September 2010.

Mazreku A, Tashko A, Civici N. 2010. Environmental impact of metallurgy on the soils and the air of Elbasan city. Buletini i Shkencave Gjeologijke. (Ndikimi mjedisor 
i zonës industriale në tokat dhe ajrin e qytetit të Elbasanit. In Albanian with English abstract).

Meço S, Aliaj Sh, Turku I. 2000. Geology of Albania. Gebrüder Borntraeger BerlinStuttgart. Pp. 193-206.

MPTI, 2000. Albanian Mining Industry report. Mining \& Process Technology Institute. Pp. 1-39.

MPTI. 1997. Studim tekniko-ekonomik dhe projekti për riciklimin e skorjeve të ferrokromit, nëpërmjet pasurimit të tyre, në uzinen e shkrirjes Burrel. Mining \& Process Technology Institute. In Albanian Pp. 1-44. (Title in English: Technical-economical study and project for the recycling of ferrochromium slags in the Burrel smelter factory).

Parris TM, Kates RW. 2003. Characterizing and measuring sustainable development. Review of Environment and Resources 28: 559-586.

Pearce DW. 1998. Cost-benefit analysis and environmental policy. Oxford Review of Economic Policy. 14: 84-100.

Pezzey J. 1992. Sustainable development concepts: An economic analysis. World Bank Environment paper nr 2. Pp. 1-71.

ProMine. http://promine.gtk.fi/ Website visted on January 2013.

Qiriazi P., Sala S. 2000. Environmental problems in Albania. In: Buchroithner M.F. (Ed.) Remote Sensing for Environmental Data in Albania: A strategy for integrated management. NATO Science series. 72/2: 13- 29.

Rivaro P, Ianni C, Massolo S, Ruggieri N, Franche R. 2004. Heavy metals in Albanian sediments. Toxicology and Environmental Chemistry 86/1-4: 85-97.

Roodman DM. 1998. The natural wealth of nations: harnessing the market for the environment, ISBN 0-393-31852-4, Published by W.W. Norton, New York, 1303

Sallaku F, Shallari S. 2003. Environmental clean-up and sustainable development of contaminated areas around the metallurgical combine of Elbasani, Albania. Options Mediterraneennes 55-62.

Sallaku F, Tota O, Huqi B. 2009. Integrated management and environmental clean-up of contaminated areas around the industrial areas of Elbasani in Albania. Eds. Stec S., Baraj B., In: NATO Science for Peace and Security Series C: Environmental Security. Energy and Environmental Challenges to Security. Pp. 403-414.

Shtiza A. 2010. Is it possible to use natural resources in a sustainable manner after intensive exploitation? 19th Congress of the Carpathian-Balkan Geological Society. Thessaloniki, Greece 23-26 September 2010. Special Publications of Geological Society of Greece.

Shtiza A, Swennen R, Tashko A. 2005. Chromium and nickel distribution in the soils, active river, overbank profiles and dust around the Burrel chromium smelter (Albania). Journal of Geochemical Exploration, 87, 92-108.

Shtiza A, Swennen R. 2005. Methods to determine speciation of chromium and importance for risk assessment: case study from Porto-Romano, Albania. First International Symposium: Cost Benefit Analysis of Geological Expertise. 14-15 October 2005, Vienna Austria. 
Shtiza A., Swennen R., Cappuyns V., Tashko A. 2009a. ANC / BNC and mobilization of $\mathrm{Cr}$ from polluted sediments in function of $\mathrm{pH}$ changes. Environmental Geology. 56/8: 1663-1678.

Shtiza A, Tashko A, Swennen R, Van den Brande A. 2009b. Impact of metallurgy on the geochemical signature of dusts, soils and sediments in the vicinity of Elbasan complex (Albania). Central European Journal of Geosciences, 1, 63-83.

Shtiza A. Swennen R, Tashko A. 2008. Chromium speciation and existing natural attenuation conditions in lagoonal and pond sediments in the former chemical plant of Porto-Romano (Albania). Environmental Geology, 53/5, 1107-1128.

Shtiza A. Tashko A. 2012. Contamination of dust particles by heavy metals: The role of sources and transportation pathways. Ed. Wouters L.B. and Pauwels M. Dust: Sources, Environmental Concerns and Control. Published by Nova Publishers.

Tashko A. 2006. Modelling contamination air history based on element content in attic dust samples. Albanian Journal of Natural and Technical Sciences, 19/20, 310319

UN Albania. http:/ $/$ www.un.org.al/subindex.php?faqe $=$ details\&id $=6 \& m n u=2$ Website visted on January 2013.

UNDP. 2010. Priority hot-spots in Albania. United Nations Development Programe.110.

UNEP, 2009. http://www.unep.org/dec/docs/env_albania.pdf Website visted on December 2012.

Van Kerkhoff L., Lebel L., 2006. Linking knowledge and action for sustainable development. Review of Environment and Resources 31: 445-477.

Vranai A, Shallo M, Xhomo A. 1997. Geology of Albania. Shtëpia Botuese e Librit Universitar. Pp. 3-361. (in Albanian).

WCED, 1987. Our Common Future: Report from the UN World Commission on Environment and Development (WCED). Oxford University Press. 